\title{
Year two of the Claraboya research project: changing faculty attitudes regarding academic library resources for improving academic performance in selected subjects and student satisfaction
}

Luis González Bravo, Pamela Menay Lagos, Gonzalo

Puentes Soto, Javier Vera Junemann, Leoncio Esmar

Gutiérrez, José Venegas Lillo, Marcela Moroni López, ${ }^{*}$

Kiyoshi Fukushi Mandiola, ${ }^{* *}$ Erwin Vega Venegas, ${ }^{* * *}$

Maruzzella Valdivia Peralta****

Artículo recibido:

12 de junio de 2014.

Artículo aceptado:

9 de mayo de 2015.

\section{Abstract}

This paper reports the research results of the Claraboya project, which through the implementation of attitudinal changes in teachers regarding reading suggestions, is focused on improving student academic performance and student satisfaction with the resources available in the campus library. The research methodology entails a comparison of pre-test result of seven indicators of satisfaction of 373 students against two random samples of students who responded to the 2013 Service Quality Survey. The research found that in six of seven variables students participating in the

* LosautorespertenecenalaUniversidadSanSebastián(USS),Chile.luis.gonzalezb@ uss.cl;pamela.menay@uss.cl;gonzalo.puentes@uss.cl;javier.vera@uss.cl;leoncio. esmar@uss.cl; jose.venegas@uss.cl; marcela.moroni@uss.cl

** UniversidadGabrielaMistralAcademicVice-Chancellor, Santiago,Chile. kiyoshi.fukushi@ugm.cl

*** Universidad San Sebastián (USS), Chile.erwin.vega@uss.cl

**** University of Concepción, Chile. mavaldivia@udec.cl

INVESTIGACIÓN BIBLIOTECOLÓGICA,Vol.30,Núm.68,enero/abril,2016,México,ISSN: 0187-358X. pp. 155-172 
Claraboya Project Research Survey (CPRS) exhibited higher average rates than those of Sample 1 and Sample 2 gathered in 2013. Moreover, the Claraboya sample exhibited statistically greater levels of satisfaction across six and five variables, respectively. To verify the second hypothesis, courses taught by the same teacher (Claraboya) were isolated and their averages compared. This hypothesis was rejected as only four of twenty-one exhibited significant differences. The scope and limitations of the study are included in conclusions.

Keywords: Library Resources; Students Satisfaction; Subject Performance.

\section{Resumen}

Segundo año del proyecto de investigación Claraboya: el cambio de actitud del profesorado con respecto a los recursos bibliotecarios encaminado a mejorar el rendimiento académico en materias selectas y niveles de satisfacción entre los alumnos

Luis González-Bravo, Pamela Menay-Lagos, Gonzalo Puentes-Soto, Javier Vera-Junemann, Leoncio EsmarGutiérrez, José Venegas-Lillo, Marcela Moroni-López, Kiyoshi Fukushi-Mandiola, Erwin Vega-Venegas and Maruzzella Valdivia-Peralta

La presente investigación informa los resultados del proyecto Claraboya, el cual estuvo centrado en mejorar dos variables: 1) satisfacción del estudiante con los recursos disponibles en la biblioteca del campus, a través de la implementación de cambios actitudinales en los académicos acerca de las sugerencias de texto, $y$ 2) el rendimiento académico de los estudiantes de los cursos participantes. Mediante un diseño preexperimental, se compararon los grados de satisfacción en siete indicadores entre una muestra por accesibilidad de 373 alumnos y dos muestras aleatorias de estudiantes participantes en la encuesta de calidad de servicio 2013. Los promedios obtenidos por los alumnos en la Encuesta de Investigación Proyecto Claraboya (CPRS) son superiores a los promedios 2013 para las muestras 1 y 2 en seis de las siete variables analizadas. Además, hay un nivel de satisfacción estadísticamente superior en seis y cinco variables respectivamente, en comparación con las muestras aleatorias. Para verificar la 
segunda hipótesis, se extrajeron los cursos impartidos por el mismo profesor en 2012 y 2013 (Claraboya) y se compararon en sus promedios. Esta hipótesis fue rechazada, en la medida en que sólo cuatro de los 21 cursos mostraron diferencias estadísticamente significativas. Finalmente, se discuten los alcances y las limitaciones de este estudio.

Palabras clave: Recursos de Biblioteca; Satisfacción de los Estudiantes; Desempeño en Asignaturas.

\section{Introduction}

San Sebastian University (USS) has implemented several initiatives to enhance student learning. The investment in bibliography and data bases in the year 2013 came to US\$ 638.000 , bringing the collection up to more than 144.000 books, of which $56 \%$ are basic bibliographies for course subjects.

Theseimprovements, however, havenotresulted in commensurate progress in student competency in the use of Ibrary resources. In this context and in recognition that efficient and effective use of the resources available in the library is as an essential element of teaching and learning processes, the Quality Assurance Vice Chancellorship (VRAC), in conjunction with the Academic Vice Chancellorship (VRA), has implemented a two-year pilot project to increase students' use of library resources and their satisfaction with said resources.

There is not enough evidence about the effects of efficient management of library resources on teaching of a particular subject or students' thoughts regarding their satisfaction with the bibliographic resources available to support their studies in such a course. This connection stands at the intersection of quality management in higher education, the use of information technologies, and the sociology of education, administration, and library science.

The processes of teaching and learning are strengthened to the extent that library resources are effectively used in classrooms, where course content is matched with the materials actually available. For teachers to fully utilize their materials and match course content to material available, however, they must go to the campus library regularly with an awareness of expected learning experiences.. This will facilitate the teaching and learning processes, making them more efficient.

On the basis of enrollment numbers each year, Chilean universities acquire basic textbooks and the university libraries acquire complementary bibliographies. At the USS, there is a permanent and increasing effort to ac- 
quire texts used to prepare students for professional careers. Additionally, the educational project of the USS and the learning environment "Vive la Experiencia USS," have been established to enrich the classroom teaching and learning processes with cultural content, while providing students greater autonomy in the search for information, the possibility of learning and applying bibliographic standards, and evaluating the appropriateness offonts used in academic tasks (De la Vega and Fukushi, 2011). This initiative is termed: "information culture in the classroom."

While one might suppose that the growing existence of texts in the library and aforementioned initiative described would result in greater student satisfaction with the texts available; however, this has not happened. In two consecutive studies of service-quality, rating on a scale from 1 to 7 , the availability of texts in the library for courses in Universidad San Sebastián has been rated by students as deficient. In 2010, the score came in at 4.8, and in 2011 it dipped slightly to 4.7 (Universidad San Sebastián, 2010, 2011).

\section{Review of Literature}

Though most research has focused on the use of library resources by students (Simisaye, 2012), there are several studies showing faculty assistance to the institutional library is often inconstant and insufficient (Popoola and Haliso, 2009; Münster, 2003).

Other studies have shown a decrease of $35 \%$ in printed books over a 10 year period (Camacho and Spackman, 2011), and ebrary (2007) reports that approximately $50 \%$ of respondents prefer to use online resources for research, class preparation and instruction, versus $18 \%$ who prefer print materials.

Although Popoola (2008) says that just a small percentage of social scientists regularly use formal databases as information resources, Münster (2003) has reported that $79 \%$ of the researchers visit the library weekly and $47 \%$ use the catalog at the same rate, though there were some differences across the diverse disciplines. For a sample of 987 graduate students, Kayongo and Helm (2010) indicate that $53.3 \%$ visit the library while $65.5 \%$ use library resources from home. Of those who visit on a weekly or daily basis, $34.8 \%$ come to sign out or return a book.

The numbers of uses seeking assistance could be driven by several causes, including insufficient technical support and access to collections, the presence of modern technology in contemporary libraries, or the huge volume of information, etc. (Jiao, Onwuegbuzie and Daley, 1997). All of this is 
very important to consider to the extent that there is evidence that effective use of library resources has an effect on the quality of teaching and of learning (Popoola and Haliso, 2009).

For example, Gaona and Villuendas (2011) report statistically significant correlations between academic performance and attitudes toward reading ( $\rho=.413, p<.001$ ), and to frequency of strategies used to find information in libraries $(\rho=.239, p<0.001)$.

Soria, Fransen and Nakerud (2013) analyzed use of libraries at the University of Minnesota during the Fall 2011 by first-year undergraduate students and found statistically significant differences in cumulative GPA (cumulative grade point average) between those who used at least one library service compared to students who did not use any.

These data are in line with research by Han, Wong and Webb, (2011) that found a correlation between the use of libraries and graduation GPA of students graduating between 2007 and 2009 at the Hong Kong Baptist University (HKBU). This positive correlation was also found by Stone and Ramsden (2013), who successfully demonstrated a statistically significant correlation between student achievement and e-resources use and book borrowing statistics. Similar findings are reported by Goodall and Pattern (2011). This pattern has also been found in high school students, where libraries visits combined with proper study habits were significantly correlated to achievement in science subjects (Aanu and Olatoye, 2011). The key mechanisms behind these correlations, apparently, are not only cognitive or associated with the development of critical judgment, but they are also motivational (Ilogho, 2011).

The fact that teachers do not adequately stimulate the use of institutional resources can occur for many reasons. For example, many of the faculties are part-time professors, with varying approaches to the use of resources and effective, valid management of bibliographies. Moreover, these approaches are distinct from those exhibited by tenure-track teachers in these areas (Washington-Hoagland and Clougherty, 2002). On the other hand, within universities, there are dissimilar expectations about the proper use of and interaction with libraries, and the fullest use of available resources (Stebelman et al., 1999).

In this way, faculty could assign certain readings for assessment that are not found in library, simply by providing copies to students. By doing so, they transmit the implicit message to students that the library's collection is not useful for educational purposes in that subject; and students might complete the course and later report dissatisfaction with resources available in the library. This dissatisfaction is not a product of an inconsistency between 
the course program and the available library resources, but between the professors' readings and those available in library. In light of the research of Lau (2001) and Pierce (2009), who suggests that a basic goal should be to encourage students to include library materials in their learning strategies, this disconnection is potentially very serious.

In sum, an attitudinal change must take place in faculties (Dierking and Fox, 2013; Khan and Pred, 2002; Kaplan, Cook and Steiger, 2006); and not only where the connections between course content and the library's resources are widely known. Faculty must also model efficient library use through an ongoing effort to assign readings that are available at the university.

The Claraboya design: the first experience of the 2012 pilot

A preliminary version the program aimed at increasing student satisfaction with the available library resources through the implementation of an attitudinal change in the professors regarding assignment of readings was designed and assessed. The central activity of this stage was a seminar attended by 18 faculty members (González et al., 2014).

In that first year, the overall structure of the seminar and the mechanisms to assess student satisfaction with the resources of the library were designed. Finally, satisfaction levels for seven indicators of and accessibility sample of 175 students of 18 pilot courses were compared to random sample of students participating in the Service-Quality Survey of 2010 and 2011. A greater level of satisfaction in all indicators was found for 2012. Five of these differences were statistically significant against 2010 survey data and as well as versus to 2011 data (González et al., 2014).

Due to the success of this initial experience, a program with greater coverage was designed for the year 2013. This program was offered to all accredited majors and those in the process of securing accreditation at the USS Campus Concepción.

\section{Aims}

To purpose of this study is to assess the the second year of the Claraboya project, which aims to: 1) increase student satisfaction with resources available in the campus library through the implementation of attitudinal changes in teachers regarding assigned reading, and 2 ) improve academic performance of students in participating courses. 


\section{Method}

\section{Hypotheses}

1) Students and teachers participating in the Claraboya 2013 program have a statistically higher level of satisfaction with the resources available in USS library than students participating in the 2013 Service-Quality Survey.

2) The mean scores obtained from Claraboya 2013 courses are statistically higher than the mean scores obtained in 2012 in the same courses.

\section{Design}

The research design entails intact groups, and pre-experimental, experimental intervention, and post-test stages. The 36 subject professors participating in the project attended the Claraboya seminar in order to train to make optimal use of library resources in connection with their respective course contents. After this intervention, students of those subjects were evaluated in two variables: 1) student satisfaction with resources available in the campus library for the course and 2) academic performance in the participant courses, which was done by comparing academic achievement of students enrolled with the same professor the year before.

\section{Intervention}

The intervention seminar titled the "Claraboya Workshop: optimizing use of bibliographies and electronic databases available in library by implementing digital indexing in subjects," was targeted at part-time teachers for the central purpose of helping teachers through attitudinal change to develop strategies for optimizing the use of academic library resources for pedagogical purposes (Steintert et al., 2006).

The seminar attended by 36 teachers lasted 15 hours, five of which were face-to-face class time (July 25, 2013). Participant courses were required to meet the following acceptance components:

1) A group project presenting a disciplinary theme in Microsoft Powerpoint which considered: a) connection between course content and virtual and physical bibliographies available in USS libraries system, b) connections with subject planning, subject programs and suggested texts, c) modeling behaviors aimed at effective use of library 
resources, and d) modeling of the incorporation of library resources into the classroom

2) Personalized follow-up throughout the semester, in which teachers receive assistance with questions and difficulties they encounter when implementing courses contents. This monitoring program was implemented using both telephone and email communication.

\section{Sample}

For the first hypothesis, an accessibility sample was used, consisting of 373 students from 17 of the 19 participant major fields: Law (5.1\%), Preschool Education (0.8\%), Nursing (7.5\%), Phonoaudiology (8.6\%), Business Administration (4.6\%), Kinesiology (8.9\%), Medicine (5.9\%), Veterinary Medicine (3.8\%), Nutrition and Dietetics (3.8\%), Dentistry (14\%), Pedagogy of Secondary Education in English (2.7\%), Pedagogy of Secondary Education in Language and Communication (1.3\%), Pedagogy in Primary Education (7.3\%), Psychology (12.1\%), Chemistry and Pharmacy (3\%), Medical Technology (9.4\%) and Social Work (1.3\%). These students (35.6\% males, $64.4 \%$ females) were enrolled in courses in Claraboya in 2013.

Of the 36 original subjects (courses) participating in the seminar, students of 34 of them answered the survey. To obtain the two 2013 ServiceQuality Survey samples, 746 persons were randomly selected from the corresponding databases to achieve 343 persons in each sample. This procedure provides two databases needed to test the first research hypothesis, consisting of 746 students who responded to the Service-Quality Survey of 2013 (in two separate random samples of 343 each) and 373 students for the experimental measurement of the 2013 Claraboya group.

To test the second hypothesis, courses taught by the same teacher in 2012 and 2013 with 20 or more students enrolled in both years were selected. The averages of the resulting 21 units of analysis were compared using the nonparametric Mann-Whitney $U$ test. All the samples showed a non-normal distribution.

\section{Instruments}

CPRS scale. To assess the effectiveness of the intervention, an adaptation of the Service-Quality Survey (which USS has been performed since 2009) was made. The 2013 version consists of 99 thematic questions, that cover the following dimensions: Library; Food and Canteen; Administrative Staff and Faculty Attention; Infrastructure, Furniture and Equipment; Technologies 
and Computer Science; Security; Photocopies; Communications; Green and Recreation Areas; Sanitary facilities and toilets; Student Assistance Services/ Scholarships and State benefits; USS University Life; Clinical Fields/Practice Centers and finally General Satisfaction. The entire survey achieved internal consistency of 0.991 (Cronbach Alpha) in 2013.

The library assessment section of the instrument contains between 7 and 9 items - depending of the year - with which students assess each service on a scale from 1 to 7. For the purposes of this study, an instrument was created called the Claraboya Project Research Survey (CPRS) that was applied in an online version using Surveymonkey. This instrument consists of seven statements that were reformulations of the items created for the Service-Quality Survey, but in this case focused on the specific participant courses in which students were enrolled (González et al., 2014) (Table 1).

Table 1. Service-Quality Survey Items and associated CPRS items

\begin{tabular}{|l|l|}
\hline \multicolumn{1}{|c|}{ Service-Quality Survey Items } & \multicolumn{1}{|c|}{ CPRS } \\
\hline Text availability in library & Text availability in library for the selected course \\
\hline Library hours of operation & $\begin{array}{l}\text { Libraryhoursofoperationwhenyouneedmaterialrequiredforthe } \\
\text { course }\end{array}$ \\
\hline Laptop loan service & Laptop loan service in library for this course \\
\hline Digitallibrarydatabasesavailability & $\begin{array}{l}\text { Digitallibrarydatabasesavailableinlibrarythatyouhaveusedinthis } \\
\text { course }\end{array}$ \\
\hline Search catalog & Material search catalog for the selected course \\
\hline study room availability in library & $\begin{array}{l}\text { Quietstudyclassroomavailabilityinlibrary(forthepurposesofthis } \\
\text { course) }\end{array}$ \\
\hline Library study room comfort & Librarystudyroomcomfort(whenrequiredfortheselectedcourse) \\
\hline
\end{tabular}

Upon final measurement, the CPRS survey attained internal consistency of 0.851 (Cronbach's Alpha). Both the pilot study and this main research used the Surveymonkey online survey system, while the CPRS was applied by email between January 10 and January 23, 2014.

\section{Variables}

The variables considered in this research are library resources satisfaction for specific courses (as measured by the CPRS), the library service dimension (extracted from the 2013 Service-Quality Survey) and the global average in the 21 courses selected for 2012 and 2013. 


\section{Data analysis}

To assess the differences between the scores of students participating in the study and the general population, two random samples of the 2013 ServiceQuality Survey were extracted. Each samlple contains the same number of students as the experimental group. Once this was done, the means of these three groups-experimental group, Sample 12013 Service-Quality (2013 S1) and Sample 2 Service-Quality 2013 (2013 S2)-were compared using Mann-Whitney $U$ test to assess the effectiveness of the program.

Moreover, the Mann-Whitney $U$ test was used to compare the averages of the 2012 and 2013 courses.

\section{Findings}

Table 2 shows the descriptive scores for the variables under study, namely satisfaction with library service (Service-Quality 2013 samples 1 and 2) and satisfaction with library resources for the selected course (by CPRS).

Table 2. Satisfaction with library resources

\begin{tabular}{|c|c|c|c|c|c|}
\hline & Sample & Mean & SD & $\begin{array}{c}\text { Lowest Score } \\
\text { Value }\end{array}$ & $\begin{array}{l}\text { Highest } \\
\text { Score Value }\end{array}$ \\
\hline \multirow[t]{3}{*}{ Text availability in library } & 2013 S 1 & 4.81 & 1.735 & 1 & 7 \\
\hline & $2013 S 2$ & 5.06 & 1.627 & 1 & 7 \\
\hline & CPRS & 5.47 & 1.614 & 1 & 7 \\
\hline \multirow[t]{3}{*}{ Libraryhours of operation } & 2013 S 1 & 5.73 & 1.483 & 1 & 7 \\
\hline & 2013 S 2 & 5.82 & 1.486 & 1 & 7 \\
\hline & CPRS & 6.20 & 1.238 & 1 & 7 \\
\hline \multirow[t]{3}{*}{ Laptop loan service } & 2013 S 1 & 5.05 & 1.673 & 1 & 7 \\
\hline & $2013 S 2$ & 5.20 & 1.666 & 1 & 7 \\
\hline & CPRS & 5.64 & 1.433 & 1 & 7 \\
\hline \multirow{3}{*}{$\begin{array}{l}\text { Availabilityofdigitaldataba- } \\
\text { ses of library resources }\end{array}$} & 2013 S 1 & 5.32 & 1.513 & 1 & 7 \\
\hline & $2013 S 2$ & 5.46 & 1.502 & 1 & 7 \\
\hline & CPRS & 5.75 & 1.445 & 1 & 7 \\
\hline \multirow[t]{3}{*}{ Search catalog } & $2013 \mathrm{~S} 1$ & 5.47 & 1.410 & 1 & 7 \\
\hline & 2013 S 2 & 5.57 & 1.457 & 1 & 7 \\
\hline & CPRS & 5.74 & 1.466 & 1 & 7 \\
\hline \multirow{3}{*}{$\begin{array}{l}\text { Availabilityoflibrarystudy } \\
\text { rooms }\end{array}$} & 2013 S 1 & 4.47 & 1.799 & 1 & 7 \\
\hline & 2013 S 2 & 4.70 & 1.829 & 1 & 7 \\
\hline & CPRS & 4.39 & 1.885 & 1 & 7 \\
\hline
\end{tabular}




\begin{tabular}{|c|c|c|c|c|c|}
\hline \multirow{3}{*}{$\begin{array}{l}\text { Comfort of library study } \\
\text { rooms }\end{array}$} & 2013 S 1 & 5.12 & 1.789 & 1 & 7 \\
\hline & $2013 S 2$ & 5.13 & 1.769 & 1 & 7 \\
\hline & CPRS & 5.48 & 1.640 & 1 & 7 \\
\hline \multicolumn{6}{|c|}{2013 S1: Random Sample 1 of Year 2013} \\
\hline
\end{tabular}

The averages obtained in the CPRS are superior to the averages for 2013 S1 and 2013 S2 for six of the seven variables analyzed: Text availability in library (2013 S1=4.81; 2013 S2= 5.06; CPRS = 5.47), Library hours of operation (2013 S1= 5.73; 2013 S2= 5.82; CPRS $=6.2)$, Laptop loan service (2013 S1= 5.05; 2013 S2= 5.2; CPRS= 5.64), Availability of digital databases of library resources $(2013 \mathrm{~S} 1=5.32 ; 2013 \mathrm{~S} 2=5.46 ; \mathrm{CPRS}=5.75)$, Search catalog $(2013$ $\mathrm{S} 1=5.47 ; 2013 \mathrm{~S} 2=5.57 ; \mathrm{CPRS}=5.74)$, availability of library study rooms (2013 S1=4.47; 2013 S2=4.7; CPRS= 4.39), Comfort of library study rooms (2013 S1= 5.12; 2013 S2= 5.13 CPRS= 5.48).

To ascertain statistical significance of these differences, the Mann-Whitney U test for independent variables was conducted. The Table 3 shows these results:

Table 3. Results of Mann-Whitney $U$ test for the independent samples

\begin{tabular}{|c|c|c|c|c|c|}
\hline & Samples & $\mathrm{N}$ & Ranks & Mann-WhitneyU & Asymp. Sig. (2-tailed) \\
\hline \multirow{4}{*}{$\begin{array}{l}\text { TextAvailabilityin } \\
\text { library }\end{array}$} & 2013 S-1 & 365 & 313.25 & \multirow[t]{2}{*}{47540} & \multirow[t]{2}{*}{${ }^{*} 0.000$} \\
\hline & CPRS & 340 & 395.68 & & \\
\hline & 2013 S-2 & 357 & 321.17 & \multirow[t]{2}{*}{50756} & \multirow[t]{2}{*}{${ }^{*} 0.000$} \\
\hline & CPRS & 340 & 378.22 & & \\
\hline \multirow{4}{*}{$\begin{array}{l}\text { Library hours of } \\
\text { operation }\end{array}$} & 2013 S-1 & 361 & 315.77 & \multirow[t]{2}{*}{48652} & \multirow[t]{2}{*}{${ }^{*} 0.000$} \\
\hline & CPRS & 342 & 390.24 & & \\
\hline & 2013 S-2 & 357 & 324.61 & \multirow[t]{2}{*}{51981} & \multirow[t]{2}{*}{${ }^{*} 0.000$} \\
\hline & CPRS & 342 & 376.51 & & \\
\hline \multirow[t]{4}{*}{ Laptoploanservice } & 2013 S-1 & 326 & 300.94 & \multirow[t]{2}{*}{43099} & \multirow[t]{2}{*}{${ }^{*} 0.000$} \\
\hline & CPRS & 317 & 343.65 & & \\
\hline & 2013 S-2 & 324 & 301.45 & \multirow[t]{2}{*}{45018.5} & \multirow[t]{2}{*}{${ }^{*} 0.001$} \\
\hline & CPRS & 325 & 348.48 & & \\
\hline \multirow{4}{*}{$\begin{array}{l}\text { Availabilityofdigital } \\
\text { databasesoflibrary } \\
\text { resources }\end{array}$} & 2013 S-1 & 332 & 296.53 & \multirow[t]{2}{*}{43170} & \multirow[t]{2}{*}{${ }^{*} 0.000$} \\
\hline & CPRS & 319 & 356.67 & & \\
\hline & 2013 S-2 & 336 & 307.98 & \multirow[t]{2}{*}{46865} & \multirow[t]{2}{*}{ *0.004 } \\
\hline & CPRS & 319 & 349.09 & & \\
\hline \multirow[t]{4}{*}{ Search catalog } & 2013 S-1 & 346 & 314.28 & \multirow[t]{2}{*}{48711} & \multirow[t]{2}{*}{${ }^{*} 0.001$} \\
\hline & CPRS & 327 & 361.04 & & \\
\hline & 2013 S-2 & 343 & 321.97 & \multirow[t]{2}{*}{51438} & \multirow[t]{2}{*}{0.054} \\
\hline & CPRS & 327 & 349.7 & & \\
\hline
\end{tabular}




\begin{tabular}{|c|c|c|c|c|c|c|}
\hline \multirow{4}{*}{\multicolumn{2}{|c|}{$\begin{array}{l}\text { Availabilityoflibrary } \\
\text { study rooms }\end{array}$}} & 2013 S-1 & 362 & 353.11 & \multirow[t]{2}{*}{59507.5} & \multirow[t]{2}{*}{0.618} \\
\hline & & CPRS & 336 & 345.61 & & \\
\hline & & $2013 \mathrm{~S}-2$ & 357 & 326.51 & \multirow[t]{2}{*}{54439} & \multirow[t]{2}{*}{${ }^{*} 0.033$} \\
\hline & & CPRS & 336 & 330.52 & & \\
\hline & \multirow{4}{*}{$\begin{array}{l}\text { Librarystudyroom } \\
\text { comfort }\end{array}$} & 2013 S-1 & 350 & 311.12 & \multirow[t]{2}{*}{52994} & \multirow[t]{2}{*}{${ }^{*} 0.007$} \\
\hline & & CPRS & 340 & 380.89 & & \\
\hline & & $2013 \mathrm{~S}-2$ & 358 & 326.96 & \multirow[t]{2}{*}{52789} & \multirow[t]{2}{*}{${ }^{*} 0.008$} \\
\hline & & CPRS & 333 & 366.47 & & \\
\hline \multicolumn{7}{|c|}{$\begin{array}{l}2013 \text { S1: Random Sample } 1 \text { of Year } 2013 \\
2013 \text { S2: Random Sample } 2 \text { of Year } 2013 \\
{ }^{*} p<0.05\end{array}$} \\
\hline
\end{tabular}

In the 2013 S1/CPRS comparison, statistically significant differences were found in six of the seven variables studied. These difference all favored CPRS as follows: Text availability in library $(p=0.00)$, Library hours of operation $(p=0.00)$, Laptop loan service $(p=0.00)$, Availability of digital databases of library resources $(p=0.00)$, Search catalog $(p=0.001)$ and Library study room comfort ( $p=0.007)$. Availability of library study rooms showed no significant differences $(p=0.618)$.

In the same way (See table above), the 2013 S2/ CPRS comparison produced statistically significant differences favoring the following five CPRS variables: Text availability in library $(p=0.000)$, Library hours of operation $(p=0.000)$, Laptop loan service $(p=0.001)$, Digital library databases availability $(p=0.004)$ and Library study rooms comfort $(p=0.008)$. Search catalog $(p=0.054)$ produced no significant differences, while Availability of library study rooms showed significant differences $(p=0.033)$, but in the opposite direction.

To check the second hypothesis, courses taught by the same teacher in 2012 and 2013 with 20 students or more enrolled in both terms were selected. The averages of the resulting 21 subjects (courses) were compared using the non-parametric Mann-Whitney $\mathrm{U}$ test. The results are shown in Table 4. To safeguard faculty privacy, acronyms for their names are used.

Table 4. Mann-Whitney U results for the 21 selected subjects

\begin{tabular}{|c|c|c|c|c|c|}
\hline Subject & Year & Means & Ranks & Mann-Whitney U & Asymp.Sig.(2-tailed) \\
\hline \multirow{2}{*}{ EK } & 2012 & 4.78 & 79.97 & 2110.5 & 0.29 \\
\cline { 2 - 4 } & 2013 & 4.62 & 68.48 & & \\
\hline \multirow{2}{*}{ AN } & 2012 & 4.53 & 50.23 & 342 & $0.000^{*}$ \\
\cline { 2 - 4 } & 2013 & 3.79 & 28.77 & & \\
\hline \multirow{2}{*}{ FVV } & 2012 & 3.83 & 21.33 & 212 & 0.086 \\
\cline { 2 - 4 } & 2013 & 4.09 & 24.9 & & \\
\hline \multirow{2}{*}{ FCQ } & 2012 & 4.09 & 29.53 & 351 & 0.170 \\
\cline { 2 - 4 } & 2013 & 4 & 27.13 & & \\
\hline
\end{tabular}




\begin{tabular}{|c|c|c|c|c|c|}
\hline \multirow[t]{2}{*}{$\mathrm{EP}$} & 2012 & 3.68 & 117.06 & \multirow[t]{2}{*}{6601} & \multirow[t]{2}{*}{0.123} \\
\hline & 2013 & 3.76 & 126.09 & & \\
\hline \multirow[t]{2}{*}{ NK } & 2012 & 3.94 & 82.23 & \multirow[t]{2}{*}{1890.5} & \multirow[t]{2}{*}{$0.000^{*}$} \\
\hline & 2013 & 3.66 & 62.17 & & \\
\hline \multirow[t]{2}{*}{ FPP } & 2012 & 4.21 & 64.99 & \multirow[t]{2}{*}{1665.5} & \multirow[t]{2}{*}{0.387} \\
\hline & 2013 & 4.18 & 63.33 & & \\
\hline \multirow[t]{2}{*}{$\mathrm{FF}$} & 2012 & 3.49 & 81.24 & \multirow[t]{2}{*}{3127.5} & \multirow[t]{2}{*}{$0.000^{*}$} \\
\hline & 2013 & 4.03 & 122.64 & & \\
\hline \multirow[t]{2}{*}{$\mathrm{FT}$} & 2012 & 3.63 & 58.17 & \multirow[t]{2}{*}{849.5} & \multirow[t]{2}{*}{$0.014^{*}$} \\
\hline & 2013 & 3.95 & 77.07 & & \\
\hline \multirow[t]{2}{*}{ HPB } & 2012 & 3.62 & 30.89 & \multirow[t]{2}{*}{440} & \multirow[t]{2}{*}{0.164} \\
\hline & 2013 & 3.74 & 34.7 & & \\
\hline \multirow[t]{2}{*}{ PM } & 2012 & 5.14 & 60.55 & \multirow[t]{2}{*}{528} & \multirow[t]{2}{*}{$0.000^{*}$} \\
\hline & 2013 & 4.48 & 33.21 & & \\
\hline \multirow[t]{2}{*}{ PIF } & 2012 & 3.96 & 34.13 & \multirow[t]{2}{*}{204} & \multirow[t]{2}{*}{$0.000^{*}$} \\
\hline & 2013 & 3.29 & 21 & & \\
\hline \multirow[t]{2}{*}{ QOE } & 2012 & 3.18 & 45.82 & \multirow[t]{2}{*}{989.5} & \multirow[t]{2}{*}{$0.000^{*}$} \\
\hline & 2013 & 3.69 & 62.33 & & \\
\hline \multirow[t]{2}{*}{$\mathrm{PCl}$} & 2012 & 3.41 & 51.64 & \multirow[t]{2}{*}{1090.5} & 0.236 \\
\hline & 2013 & 3.16 & 47.83 & & \\
\hline BT & 2012 & 3.62 & 41.84 & 853.5 & 0.2 \\
\hline & 2013 & 3.78 & 45.84 & & \\
\hline MPB & 2012 & 4.04 & 30.84 & 425.5 & 0.14 \\
\hline & 2013 & 4.22 & 35.54 & & \\
\hline PAP & 2012 & 3.39 & 66.61 & 1923.5 & 0.069 \\
\hline & 2013 & 3.58 & 76.03 & & \\
\hline PGV & 2012 & 4 & 29.5 & 360 & 0.065 \\
\hline & 2013 & 3.92 & 27.35 & & \\
\hline FOO & 2012 & 4.21 & 96.13 & 3798 & 0.063 \\
\hline & 2013 & 4.09 & 87.89 & & \\
\hline IGT & 2012 & 3.88 & 48.38 & 1127.5 & $0.000 *$ \\
\hline & 2013 & 4.34 & 66.54 & & \\
\hline PIFII & 2012 & 4.05 & 44.41 & 683 & 0.080 \\
\hline & 2013 & 3.87 & 38.53 & & \\
\hline
\end{tabular}

\section{$\mathrm{P}<0.005$}

As shown in Table 4, statistically significant differences in favor of the 2013 intervention were found in 4 of the 21 subjects evaluated, corresponding to $19 \%$ overall. 
This paper reports on the research is the middle stage of a pioneer project in Chile for optimizing of the use of library resources for academic purposes. A higher level of satisfaction was found in six of the indicators measured by the CPRS scale. The study found that six of these indicators showed significant differences against $2013 \mathrm{~S} 1$ and five (5) indicators against 2013 S2. These results serve to provide substantial support for the validity of the first research hypothesis.

An analysis of this variation reveals that the most important indicator for the purposes of this research, i.e., "text availability," shows statistically significant differences in both comparisons. Since the S1 and S2 samples were selected randomly, these results corroborate the data found in the preliminary approach by the researchers (González et al., 2014) and they underscore the importance of implementing this program at the national level.

As mentioned before, these results come in addition to the other five and four indicators with significant differences found respectively in the two comparisons. Of these, the increased levels of satisfaction with library hours of operation may indicate a positive feedback: as students visit the library more frequently, they become increasingly familiar with and better adapted to the library schedule.

In the view of the authors of this study, the fact that satisfaction with the search catalog did not improve after intervention is due to the fact that students in the experimental courses were required to use the library by faculty. Moreover, participating faculty often provided catalogue codes needed to find required reading.

The second research hypothesis must be rejected because no effect on academic performance of students enrolled in the selected courses was found against the either the 2012 or 2013 grade average, a finding that is not consistent with the findings reported by Gaona and Villuendas (2011), Soria, Fransen and Nakerud (2013), Han, Wong and Webb (2011) and Stone and Ramsden (2013).

It is important to highlight, however, that the aforementioned research studied the correlation between the students' academic performance and the use of library resources, but not the impact of an intervention on the course's overall performance in two different years.

This is important, to the extent that the development of skills for the use of existing library resources benefits students over the course of their entire academic life. On the other hand, there are many factors that affect the overall performance of a course, including the number of students enrolled and the individual characteristics of the students. 
In fact, of the courses participating in the comparison, five (5) are offered in the first year of the respective majors, and there is evidence in the USS that the overall performance of students admitted in 2013 was lower than those admitted on 2012 (Programa CREAR, 2013).

Finally, it should be pointed out that, in terms of faculty satisfaction and teaching quality, the effectiveness of programs aimed at behavioral changes through attitudinal changes has been sufficiently documented (Dierking and Fox, 2013; Khan and Pred, 2002; Kaplan, Cook and Steiger, 2006), but student satisfaction and organizational development has not been documented to nearly the same extent (Steintert et al., 2006).

An analysis by major or by student within a full-fledged experimental design or an analysis of the effectiveness of the intervention, comparing participating students vs. unexposed students in a given year, are potential areas for further research. In the same vein, the limitations of this research were related to the generalizability of the results and the nature of the research design. The pre-experimental design does not utilize random selection of participants in the Claraboya Seminary or in a random a control group, and therefore cannot asses the second hypothesis or allow the researchers to draw conclusions or assert causal connections between the variables. These issues should be considered limitations of this research and areas for future study.

\section{Works Cited}

Aanu, E., and Olatoye, R. (2011). "Use of library resources, study habit and science achievement of junior secondary school students." Educational Research 2 (7): 1265-1269.

Camacho, L., and Spackman, A. (2011). "Transitioning to E-books: Usage and Attitudes Among Business Faculty." Journal of Business and Finance Librarianship 16 (1): 33-45.

De la Vega, R., and Fukushi, K. (2011). Plan de Requerimientos "Vive la Experiencia USS". Santiago: Universidad San Sebastián.

Dierking, R., and Fox, R. (2013). "Changing the Way I Teach": Building Teacher Knowledge, Confidence, and Autonomy." Journal of Teacher Education 64 (2): 129-144.

ebrary (2007). 2007 global faculty e-book survey. http://www.ebrary. com/corp/collateral/en/Survey/ebrary_faculty_survey_2007.pdf

Gaona, J., and Villuendas, E. (2011). "Relationship between reading habits, university library and academic performance in a sample of psychology students." Revista de la Educación superior 15 (157): 55-73. 
González, L.; Puentes, G.; Vera, J.; Esmar, L.; Venegas, J.; Moroni, M.; Fukushi, K.; Vega, E., and Valdivia, M. (2014). "Evaluación de la efectividad de un programa piloto de optimización del uso de los recursos de Biblioteca en la Universidad San Sebastián y satisfacción de los estudiantes, basado en el cambio actitudinal de 18 académicos." Revista Estudios Pedagógicos 40 (2): 189-201.

Goodall, D., and Pattern, D. (2011). "Academic library non/low use and undergraduate student achievement. A preliminary report of research in progress." Library Management 32 (3): 159-170.

Han, S.; Wong, R., and Webb, T. (2011). "Uncovering Meaningful Correlation Between Student Academic Performance and Library Material Usage." College and Research Libraries 72 (4): 361-370.

Ilogho, J. E. (2011). “Bibliotherapy: an option for enhancing students' motivation for academic achievement in Iganmode Grammar School and Grait International College, Ota - Ogun State." IFE Psychologia 19 (2): 437-461.

Jiao, Q. G.; Onwuegbuzie, A. J., and Daley, C. E. (1997). “Factors Associated with Library Anxiety." Paper presented at the Annual American Educational Research Association Conference, Chicago, Illinois, March 24-28. http://files.eric.ed.gov/fulltext/ED4168 95.pdf

Kahn, J., and Pred, R. (2002). "Evaluation of a Faculty Development Model for Technology Use in Higher Education for Late Adopters." Computers in the Schools 18(4): 127-150.

Kaplan, M.; Cook, C. E., and Steiger, J. (2006). "Using Theatre to Stage Instructional and Organizational Transformation." Change: The Magazine of Higher Learning 38 (3): 32-39.

Kayongo, J., and Helm, C. (2010). "Graduate students and the library: A survey of research practices and library use at the university of Notre Dame." Reference and User Services Quarterly 49 (4): 341349.

Lau, J. (2001). “Faculty-librarian collaboration: A Mexican experience." Reference Services Review 29 (2): 95-105.

Münster, I. (2003). “La Biblioteca Max von Buch de la Universidad de San Andrés y sus investigadores: Segunda parte de Un estudio de las necesidades de información, hábitos y características de Investigadores en Humanidades y Ciencias Sociales." Información, Cultura y Sociedad (9): 53-73.

Pierce, D. (2009). "Influencing the now and future faculty: Retooling information literacy." Music Library Association. Notes 66 (2): 233 248.

Popoola, S. O. (2008). "The Use of Information Sources and Services and Its Effect on the Research Output of Social Scientists in Nigerian Universities." Library Philosophy and Practice. http://www. webpages.uidaho.edu/ mbolin/popoola.htm 
Popoola, S., and Haliso, Y. (2009). "Use of Library Information Resources and Services as Predictor of the Teaching Effectiveness of Social Scientists in Nigerian Universities." African Journal of Library, Archives and Information Science 19 (1): 165-177.

Programa CREAR (2013). Resultados del Programa de Nivelación Inicial y Continua 2013. Santiago: Universidad San Sebastián.

Simisaye, A. O. (2012). "Faculty use of university library resources: A study of Tai Solarin University of Education, ljagun, Ogun State, Nigeria." Library Philosophy and Practice. http://search.proquest. com/docview/1349931914?accountid=26111

Soria, K.; Fransen, J., and Nakerud, S. (2013). "Library Use and Undergraduate Student Outcomes: New Evidence for Students' Retention and Academic Success." Portal: Libraries and the Academy 13(2): 147-164.

Stebelman, S.; Siggins, J.; Nutty, D., and Long, C. (1999). "Improving Library Relations with the Faculty and University Administrators: The Role of the Faculty Outreach Librarian." College and Research Libraries 60 (2): 121-130.

Steinert, Y.; Mann, K.; Centeno, A.; Dolmans, D.; Spencer, J.; Gelula, M., and Prideaux, D. (2006). "A systematic review of faculty development initiatives designed to improve teaching effectiveness in medical education: BEME Guide No. 8." Medical Teacher 28 (6): 497-526.

Stone, G., and Ramsden, B. (2013). "Library Impact Data Project: Looking for the Link between Library Usage and Student Attainment". College and Research Libraries 74 (6): 546-559.

Universidad San Sebastián (2010). Informe Descriptivo Estudio Calidad de Servicio 2010 Universidad San Sebastián. Santiago: Universidad San Sebastián.

(2011). Informe Descriptivo Estudio Calidad de Servicio 2011. Universidad San Sebastián. Santiago: Universidad San Sebastián.

Washington-Hoagland, C., and Clougherty, L. (2002). "Faculty and staff use of academic library resources and services: A university of lowa libraries' perspective." Portal: Libraries and the Academy 2 (4): 627-646.

Para citar este artículo como revista electrónica:

González Bravo, Luis et al. 2016. "Year two of the Claraboya research project: changing faculty attitudes regarding academic library resources for improving academic performance in selected subjects and student satisfaction". Investigación Bibliotecológica: Archivonomía, Bibliotecología e Información.68: 155-172. Aquíseagregala dirección electrónica (Consultado el día-mes-año) 


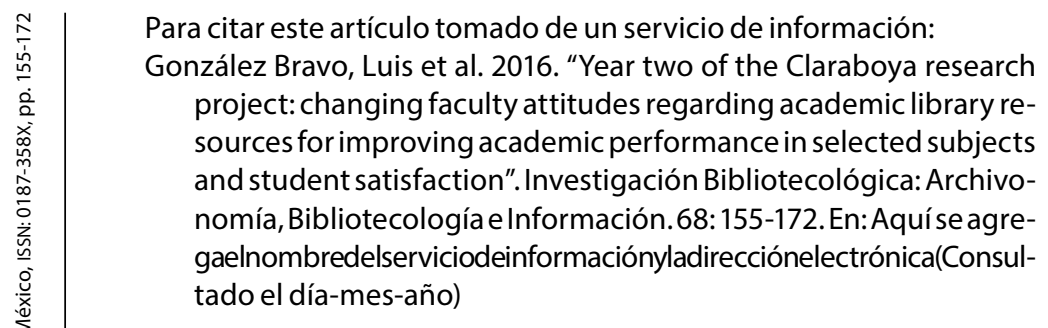

